\title{
Intra vs. extra-regional connectivity of the Black Sea port
}

\section{system}

\author{
Kateryna GRUCHEVSKA, University of Antwerp, Belgium \\ Theo NOTTEBOOM, University of Antwerp, Belgium \\ César DUCRUET, CNRS \& UMR 7235 EconomiX, Nanterre, France
}

Pre-final version of the chapter published in Ducruet C. (Ed.) (2017) Advances in Shipping Data Analysis and Modeling. Tracking and Mapping Maritime Flows in the Age of Big Data, Routledge Studies in Transport Analysis, pp. 107-128.

The Black Sea port system is generally considered as a secondary port system in the European port scene. Though located next to the East Med ports, it is not situated along the main east-west shipping routes, due to the existence of the Bosporus Strait, which forms a nautical link between the two seas. The region's economic position is being affected by a range of developments of a more global nature such as (i) nearshoring, (ii) the shift of EDC development from West to Central and Eastern Europe, (iii) SECA regulations in the North and Baltic Seas, (iv) the growth of East Med ports, (v) the Silk Road project revitalization, (vi) Suez Canal expansion, etc. However the political and economic instability of the Black Sea states (mainly Russia and Ukraine) could counterwork global trends and prevent the region from potential dynamic development. The aforementioned global and regional circumstances can significantly affect the configuration of shipping patterns to/from Europe and thus alter the position of Black Sea ports in the global shipping network.

Several empirical studies on maritime network analysis can be found in the extant literature. However, Ducruet et al (2010) argue that these studies are scarce and quite fragmented. Moreover, shipping connectivity literature shows an absence of a systematized comprehensive analysis of the maritime network of the Black Sea. This chapter addresses shipping dynamics in the Black Sea with a specific focus on internal and external connectivity dynamics, with reference to the wider field of network analysis. Our central research question is whether the foreland regionalization and globalization of Black Sea shipping networks also depends on a certain degree of intra-regional connectivity. In transport geography, intermediacy and centrality (Fleming and Hayuth, 1994) well describe the spatial qualities that enhance the traffic levels of transportation hubs and hence indicate which places are favorably located within transport systems. Centrality focuses on the port vicinity 
being a point of origin and destination of traffic to/from adjacent areas. At the same time intermediacy focuses on the port being a point of transit between different systems of circulation. Intermediate ports/airports as defined by Fleming and Hayuth (1994) are the enroute intermediate locations between important origins and destinations chosen as way stops, route conjunctions, break-in-bulk points, gateways etc.

Yet, this chapter wishes to introduce another network-related concept, namely vulnerability, which better describes how certain port nodes grow at the expense of others, the latter becoming peripheral (Fraser et al., 2016) or dependent upon external hubs (Ducruet et al., 2010). While the centralization (or concentration) level of port systems is a classic approach in transport studies (Notteboom, 2006), it had been only recently applied to shipping networks in particular regions (see a comparative perspective in Mareï and Ducruet, 2015) or at the global scale (Ducruet and Notteboom, 2012b). This chapter goes one step further, by relating the internal organization of a given regional network, here the Black Sea, taking into account the external dynamics taking place in the vicinity and in the rest of the world. Nevertheless, it goes beyond the analysis of the maritime forelands of individual ports (Wang and $\mathrm{Ng}, 2011$ ). We complement this quantitative analysis of shipping data with qualitative information about past and current projects on a local or national scale, and compare our results with other data sources (for other analyses of transnational port systems, see Chapters 5, 9, 11, 19, 23, and 24 on Taiwan Strait, the Arctic, the Mediterranean, the USSR, Northwest Africa, and the Indian subcontinent, respectively).

First we will set the scene of the Black Sea container port system, by assembling and synthesizing complementary data and knowledge about Black Sea ports and shipping routes, such as by using the liner shipping connectivity and logistics performance index developed by UNCTAD. Then, we will perform a network analysis of the Black Sea region looking at traffic shifts and topological dynamics from the late 1970s up to the present day. Finally, we conclude with the main findings of the chapter and outline the possible future research avenues.

\section{General profile of the Black Sea container port system}

Notwithstanding the fact that the Black Sea region accounts for only $2.5 \%$ of global seaborne trade, (while the leading European trade region -the North Sea- accounts for about 17\%) it is an important area of development due to its geographical size and resource/consumption base. The Black Sea container port system is among the world's fastest growing markets with a cargo growth rate in 2014 of $6 \%$ p.a., and a CAGR (1998-2014) of 14\%. In the same period, the global CAGR amounted to 9\%, South Asia 11\%, Africa $11 \%$ and Western Europe 
5\% (UNCTAD). The Black Sea container port system consists of 11 ports with annual container traffic of about $2.6 \mathrm{mln}$. TEU (2014).

What became clear in recent decades is the growing share of container traffic in the Black Sea region (Figure 8.1), which traditionally specializes in bulks, as a heritage of the former Soviet/ socialist period. In the late 1970 s, container traffic represented no more than $2.5 \%$ of the total, followed by $5.0 \%$ one decade later, $13.4 \%$ in the late 1990 s, and $25.7 \%$ in 2008 . Such a trend mainly occurred at the expense of bulks, with solid bulks and liquid bulks declining from $29.0 \%$ and $53.3 \%$ in 1977 to $19.4 \%$ and $35.9 \%$ in 2008, respectively. This reflects a growing diversification of Black Sea ports, as reflected by world trends (Ducruet, 2017) but at the same time, the direct effects of liner shipping strategies and actions performed in the region.

[Figure 8.1]

The main container lines serving the Black Sea are MSC, Maersk, Zim, Arkas, Emc; a detailed overview of which is presented in Table 8.1. The peculiarity of the Black Sea is that only few ports are called at directly by shipping lines: Constanta (Romania), Odessa and Illyichevsk (Ukraine), and since 2011 also Yuzhnyi (Ukraine) and Nororossyisk (Russia). As from 2003, the size of the container vessels entering the Black Sea grew from 2500 TEU up to 10,000 TEU at the present time. A significant restriction on vessel size in the Black Sea is the Bosporus Strait on account of its physical constraints. Thus, container shipping lines can deploy vessels of up to 10,000 TEU for the Black Sea, while vessels of up to 18,000 TEU are already calling at ports in the Mediterranean. Furthermore, shipping economics would not allow for much bigger ship sizes because of the current stagnation in demand -in 2014 and 2015 the total regional container demand dropped by 1-2\% per annum. Shipping lines call at the Black Sea basin mainly in a shared calling pattern (Table 8.2). There are only two (out of four previously existing) direct services left between the ports of the Black Sea and the Far East: the Asia-East Med Express service of Zim/OOCL and joint Ocean three/Yang Min service. The changes in the calling patterns accrued during 2015 and 2016 due to the decreased Black Sea demand and low freight rates. Other weekly services are the Ecumed service (Maersk Line, South America, annual capacity of 150,000 TEU) and a Maersk service connecting the Indies and the Middle East to the Black Sea.

[Table 8.1]

[Table 8.2]

These services involve line-bundling operations with calls at 3 to 4 Black Sea ports. Roughly, half of the current containers handled in the Black Sea ports are shipped using direct calls, while the other half is feedered from hub ports in the East Med such as Istanbul, Piraeus and 
to a lesser extent Thessaloniki, Gioia Tauro etc. The Mediterranean ports play an increasing role in the Far East-Black Sea trade. As from the mid-1990s, the Mediterranean witnessed an active development of hub-feeder container systems as well as short sea shipping networks driven by the growth of the container volumes serving the southern part of Europe (Notteboom, 2010).

Since 2001, Black Sea ports have attracted global terminal operators. The first entrants were HHLA in Odessa port (2001) and NCC in Novorossiysk port (2002). A second wave of entrants included DPW in Constanta (2004) and NCC in Illichivsk (2005). The last big inflow of global terminal operators included APMT in Poti (2011) and a joint involvement of CMA-CGM in Odessa, together with a local terminal operator (2008). In the coming years two new green field ports in the Black Sea are expected to start operations, namely in Anaklia in Georgia and Taman port in the Russian Federation.

Figure 8.2 provides an overview of container throughput in Black Sea ports. Last year's traffic decline in Black Sea ports is in sharp contrast to the strong growth witnessed by Piraeus and Turkish deep-sea ports near the Sea of Marmara. This demonstrates that shipping lines increasingly prefer a hub-feeder model in the Med to service the Black Sea area instead of direct deep-sea calls in the Black Sea. Constanta's container throughput fell sharply from 1.38 million TEU in 2008 to $0.59 \mathrm{~m}$ TEU in 2009. 2015 witnessed a stabilization in port traffic with limited growth of up to $0.68 \mathrm{~m}$ TEU. Early on in its development, Constanta was very much seen as the transshipment gateway for the Black Sea and registered an incidence of around $75 \%$ in 2008. However, the crisis of 2008 hit the regional economies and the shipping lines that likewise motivated the later change in their liner services in search of cost-efficient logistic solutions. A number of direct services from the Far East into the Black Sea region were cancelled, negatively affecting Constanta's transshipment volumes. As a result, by 2012 almost three-quarters of the volumes handled at the port consisted of local import and export containers, with the remaining quarter being transshipment.

[Figure 8.2]

The slowdown of Ukrainian port traffic in 2012 was connected to the regulatory changes in customs procedures, while ports lost between 50,000 to 100,000 TEU in favor of Hamburg and Baltic ports and to a lesser extent to Romania (Informal BG Black Sea Container Market report 2014). The Ukrainian economy and container turnover started to stagnate at the end of 2013, due to the political crisis followed by more turbulent times and the annexation of Crimea by the Russian Federation in May 2014, with armed conflict in the East of Ukraine shortly thereafter. As an outcome of these events, the drop in container traffic in 2014 represented about $14.4 \%$ p.a. followed by a more drastic fall in 2015 of $29 \%$ p.a. Russia showed a negative container growth rate of $-0.3 \%$ in 2014 in contrast to the growth of $10.1 \%$ 
in 2013, which represents a very drastic change. Romania had a 4.9\% growth rate in 2014 compared to $14.34 \%$ in 2013 . The same dynamic was shown by the Bulgarian ports with a growth rate in 2014 of $8.4 \%$ as against 6.5\% in 2013 (Informal BG Black Sea Container Market report 2014).

Connectivity measures at country level using the UNCTAD Liner Shipping Connectivity Index (LSCI) as well as the Logistics Performance Index (LPI) global rankings are based on Hoffman (2012) to illustrate recent trends among studied countries (Figures 8.3 and 8.4). We applied the LSCI and LPI to the (i) Black Sea countries as well as to (ii) their East Med (Med) neighbors and finally to (iii) North European (NE) countries. The latter show the best performance in Europe based on both indicators. The average LSCl and LPI in the Black Sea is constantly increasing with the average (AVG) growth trend. If Russia is removed from the $\mathrm{LSCl}$ analysis, Ukrainian ports are leading, based on the $\mathrm{LSCl}$ index, even overtaking Romania as from 2009, since Constanta port has stopped playing a hub role in the Black Sea.

[Figure 8.3]

[Figure 8.4]

Figure 8.4 on the LPI shows the same general outcome as the LSCI, with the sole difference that Ukraine is no longer a leader in the Black Sea, having been passed out by its Western neighbors Romania and Bulgaria. The LPI leadership of these states can be partially explained by the fact that they joined the EU in 2007 and since then needed to improve and bring their logistics efficiency closer to EU norms (clearance processes, quality of trade and transport infrastructure, etc.). Ukraine is the third best performer in the Black Sea based on the LPI index.

\section{Connectivity shifts of the Black Sea port system}

In this section, we use the Lloyd's List Intelligence (LLI) database to analyze and map the traffic level and connectivity of Black Sea ports in the last 40 years or so. Such a long period allows us to grasp essential features on how the network had actually evolved across different geopolitical and technological phases, from limited containerization to the era of mega-ships. The daily movements of fully cellular containerships were aggregated each year during the month of June and transformed into global and regional port-to-port adjacency matrices. Inter-port links are defined as follows: ports are connected when they belong to the voyage of the same vessel during the 30 years of circulation. The amount of flows (traffic volume) in such a weighted, but undirected, network corresponds to the product between call frequency and vessel capacity measured in deadweight tons (DWTs). We then apply 
conventional graph-theoretical measures to the matrix, or graph, in order to extract its topological properties, reveal the geographic distribution of connectivity, and map the port hierarchy.

\section{Traffic distribution and network topology}

One first step toward understanding past and current dynamics affecting the Black Sea port system is to compare total vessel traffic with the topological size (nodes, links) of the regional network (Figure 8.5). Missing years directly reflect the low containerization rate of the region in the initial period as well as the political instability and transition of the early 1990s due to the collapse of the USSR in 1991 and Eastern Block dismantlement (see also Chapter 19 for a more in-depth analysis of the impact of USSR collapse on related shipping networks). After such a major shock, especially from the mid-1990s onwards, we observe a fast and continuous traffic growth despite slight fluctuations. Traffic volumes and network size grew in parallel with each other, with the gradual containerization of Black Sea ports. This evolution reflects the increasing concentration of shipping traffic among Black Sea ports (cf. Gini coefficient), but at the same time, a decreasing share of the largest ports (cf. Herfindahl index or $\mathrm{HHI}$ ) probably due to the polycentricism of the system and the emergence of small and medium-sized ports.

[Figure 8.5]

The spread of containerization, however, tended to reinforce existing (or to create new) inequalities within the region, which are best visible at country level (Figure 8.6). After a period of minimal traffic (1977-1997), the main players on the Black Sea scene became Ukraine, Romania and Bulgaria, namely the Western sub-region closest to Western Europe. In comparison, and given their relatively shorter coastline and fewer numbers of ports, Russia, Georgia and Turkey remained rather peripheral in the system, in both absolute and relative terms. These ports serve relatively narrow hinterlands and are at a certain remove from the core European markets; therefore, their traffic is limited. One exception is Russia, which rapidly and recently acquired a sizeable portion of the total Black Sea container traffic. Some explanatory factors include transit trade for the Russian Federation itself through third countries, such as Ukraine; port expansion in Russia, such as in Novorossiysk; and conjectural phenomena, such as the Sochi Olympic Games in 2012 fostering traffic growth to build and cater for the new villages. In addition, the somewhat protectionist Russian attitude in terms of trade favored domestic ports over others to serve Russian hinterlands.

[Figure 8.6] 
Externally, the connectivity of Black Sea ports as a whole went through a similar trend of growth (Figure 8.7, left). Despite some fluctuations, the number of links and nodes connecting the Black Sea with the rest of the world increased somewhat gradually and in parallel until the late 1990s, notwithstanding a noticeable decline in the number of ports after 1990. After 1998, a second phase was marked by rapid growth, despite some gaps in 2001-2003, 2006, and 2013. In the early 2000s, the freshly built Black Sea republics were still in a shaky economic state, namely undergoing rejuvenation after the early 1990s. The case of 2013 is better explained by the delayed impacts of the 2008-2009 global financial crisis in addition to local geopolitical conflicts leading to currency devaluation, high inflation, and less demand for containers. In terms of traffic volume and share (Figure 8.7, right), extraregional vessel tonnage increased in similar ways than connectivity, albeit with an earlier take-off, namely in the mid-1990s. Following the collapse of the USSR, many Black Sea ports in the new republics were forced to diversify their traffic and adopt new technologies (i.e. containerization) to adapt to global standards and compensate the amputation of their formerly vast hinterlands (Thorez, 1998). Each port gateway used to operate separately in the Soviet era, connecting the USSR with the outside world, which explains the very high share of extra-regional traffic in the total Black Sea traffic in the early period, around $90 \%$. For the same reasons cited above, post-Soviet ports strove to develop and multiply their external connections while increasing their mutual links. This resulted in a sharp decline of extra-regional traffic share from around $80 \%$ in the late 1990 s to about $50 \%$ in 2006 , the lowest value. During the last decade, however, extra-regional traffic has boomed and reached nearly $70 \%$ in 2015 . As mentioned earlier, the role of Turkish ports as intermediate nodes ensuring the Black Sea's connectivity is well revealed by Turkey's rapidly growing share in total extra-regional traffic, from around $10 \%$ in the mid-1990s to around $60 \%$ in 2015.

[Figure 8.7]

The geographic distribution of Black Sea ports' maritime forelands brings complementary elements to the understanding of their global and regional connectivity (Figure 8.8). At the level of world regions or continents (left figure), Europe takes the lion's share of total extraregional traffic with $\mathbf{7 7 . 4 \%}$ on average over the whole period. This share had been relatively stable, except for a decline in the period 2004-2011, with an average of 65.3\%. Geographic proximity to Europe, in addition to the fact that Western Europe had long played a crucial role for socialist trade either for transit or real commerce, is the main explanatory factor. The Americas as a whole never played any significant role for Black Sea container shipping, nor did Oceania (zero traffic), so that Europe is only followed by Asia and Africa. Although geographic proximity also explains, at least in part, the heavier weight of West Asia (i.e. Near East, Middle East, Indian subcontinent) compared with East Asia, the latter became more 
important than the first during the period 2004-2013 despite physical distance. Yet, the recent period was clearly impacted by a fall in demand (i.e. $15 \%$ decline in Black Sea-Asia trades) in 2015 and again in 2016 (Gerden, 2015; Ugurlu, 2017). Africa as a whole, despite a relatively low traffic share (3.4\% on average), maintained its share in the recent decade (2003-2016) with a 5.6\% average, probably due to increased transshipment through Egyptian ports such as Alexandria, Damietta, and Port Said. When zooming into Europe (right figure), we see that South Europe in general had always been dominant compared with North Europe, the latter reaching a peak in 1994 (28.1\% of Black Sea's total European traffic) but only during the 1984-2001 period. Thus, there has been a shift of Black Searelated transshipment activities from North to South Europe over time. An important change in regional foreland distribution is the drastic shift from Southwest Europe dominance to East Med dominance. Southwest Europe accounted for $62.9 \%$ on average of the Black Sea's total European traffic in the period 1977-2004, while the East Med reached $72.9 \%$ during the rest of the period, with $81.0 \%$ in 2016 . Such an inversion is directly attributable to the new competitive position and attractiveness of East Med ports for transshipment activities in the Med and the Black Sea. It is also driven by the Turkish effect, as mentioned above.

[Figure 8.8]

\section{Multiple linkage analysis}

Within any regional port system, it is fundamental to understand the evolution of port hierarchy but also the way in which shipping connectivity spatially spreads among port nodes. To achieve such a goal, we defined eight sub-periods and for each of them we calculated the sum of vessel traffic by port. In addition, we mapped a simplified shipping network made up of the two largest flows of each port in terms of traffic volume. The loss of information is thus counterbalanced by a better view of the network's backbone, with the hypothesis that the multiple linkage analysis can reveal which hubs dominate the port system and the system's degree of centralization (Figure 8.9). The size of nodes corresponds to total vessel traffic including extra-regional traffic.

[Figure 8.9]

Before analyzing the results, it is important to note that over the entire period, we found no evidence of a centralization process in the Black Sea. The Gamma Index, which corresponds to the proportion of actual links in the total maximum possible number of links among connected ports, did not show any particular trend. The index oscillates around $40 \%$ over time, although from 2010 onwards the average index went down to $32-33 \%$. This slight decrease suggests a simplification of the network in recent years, but it remains rather moderate. Such a result indicates that the Black Sea port system might be more externally than internally centralized, due to the absence of a hub-and-spokes configuration in the 
region. Based on the 8 periods under consideration, the constantly connected top 5 ports (i.e. Constanta, Odessa, Chornomorsk, Varna, and Mariupol) exhibit a very high and significant relationship $\left(R^{2}=0.8945\right)$ between their average traffic size and the standard deviation of their traffic growth rates, thereby depicting a well-integrated region or range (Lemarchand and Joly, 2009).

Apart from providing a clear picture of the port hierarchy, Figure 8.10 sheds more light on the evolution of the dominant shipping linkages within the Black Sea. While Constanta and Odessa are connected only externally in the first period (1977-1984), Mariupol appears as a pivotal port for the other periods. However, Mariupol sustained its activity in the two subsequent periods, but without being connected internally to the region. North-South linkages in the west part of the region then dominate, notwithstanding the emergence of East-West transversals in subsequent periods. Constanta appears as the largest and best connected port, but without centralizing the whole network, as a number of dominant linkages connect Eastern ports, and a number of secondary nodes do not depend on Constanta for their connectivity. Geographic proximity has some visible influence on the sub-regionalization of the Black Sea, between East and West, but remains moderate. As time passes, the network becomes more and more complex and does not exhibit any particular pattern. Perhaps this relates to the absence of a single or twin-hub system internally. It could also reveal, indirectly, the growing dependence of Black Sea ports upon external Med hubs, such as in Turkey.

\section{Conclusion}

This chapter investigated the changing internal and external trends affecting the past and current evolution of the Black Sea port system and liner shipping network. Due to a low containerization rate and a peripheral situation from major container shipping routes in the 1970s-1990s, this region exhibited a rather peculiar pattern at the time, characterized by low internal connectivity, extraverted flows, and small traffic and network size. If the gradual and rapid increase of traffic volumes (especially from the mid-1990s) inevitably resulted in growing concentration around a few large ports, network analysis did not confirm the emergence of a centralized system, or hub-and-spokes configuration, within the Black Sea itself. More likely is the growing dependence of these large ports upon external transshipment hubs such as in Turkey, for instance, the latter having absorbed the lion's share of the Black Sea's external connectivity in the past decade or so. Our main findings thus suggest that the Black Sea port system does not have a clear structure, due to the absence of a hub-and-spokes configuration locally, and therefore a mismatch between port traffic volume and port centrality, except for Constanta, which took on hub functions for some time until 2008. Thus, contradictory forces characterize the region, between regional integration and network centralization, due to its polycentric structure. 
Based on historical analysis and recent developments in the region we conclude that the outlook for Black Sea port connectivity does not seem set to change drastically. Given the fact that (i) the Black Sea remains a remote area; (ii) the economic situation in the region in the near future is expected to gradually grow and (iii) it is hard to estimate the future impact of the new Silk Road development on the Black Sea ports, we forecast a moderate growthstable scenario. When compared with existing literature on Black Sea ports, this chapter provides mixed evidence, such as the observed growth of direct calls vs. feeder (Gouvernal et al., 2012), which is reflected in the gradual increase of the LSCI index but not in the other analyses. Indirectly, our results at least partially confirm the findings of Notteboom and De Langen (2015) in relation to the fast growth of South European ports, with our chapter bringing new evidence about the regional shift from West Med to East Med as the Black Sea's main external connector. The work by Ducruet and Notteboom (2012) on the global shipping network underlined the emergence of nodal regions around the ports of Constanta, Izmir, and Ambarli, the first being also considered in this chapter a major node but not yet the principal hub of the Black Sea, which remains more polycentric. Our findings also support those of Seoane et al. (2013) due to that West-East shift in external connectivity; one explanation for this in recent years being the suspension of 2 out of 4 direct Far-EastBlack Sea services (2015-2016). These elements might explain why Li et al. (2015) observed a decline in the Black Sea's global shipping centrality despite its overall traffic growth. The absence of traffic concentration internally had been already underlined by Gruchevska and Notteboom (2014), with the notable exception of Novorossiysk port, so our study is in line with their work, though adding new evidence from a relational (network) perspective beyond traffic volumes taken in isolation. All in all, this study shows us how important the geographical scale of analysis is when it comes to shipping flows and networks. The Black Sea in itself might not (yet) be a well-organized system; its internal dynamics cannot be understood without taking into account the centralization of its own flows through external hubs. This contribution ties in well with academic literature on the evolution of the vulnerability and hub-dependency of shipping networks (Ducruet, 2008), especially when looking at the impact of both technological and geopolitical factors affecting trade and logistics.

\section{Acknowledgements}

The research leading to these results has received funding from the European Research Council under the European Union's Seventh Framework Programme (FP/2007-2013) / ERC Grant Agreement n. [313847] "World Seastems". 


\section{References}

Drewry (2014) Slow-steaming keeps overcapacity at bay. Accessed 3 February 2015: http://worldmaritimenew.com/archives/140404/drewry-slow-steaming-keeps-overcapacityat-bay/

Drewry (2015) Container lines in for three years of overcapacity pain. Accessed 3 February 2015: http://worldmaritimenews.com/archives/173588/drewry-container-lines-in-for-threeyears-of-overcapacity-pain/

Ducruet C. (2008) Hub dependence in constrained economies: The case of North Korea. Maritime Policy and Management, 35(4): 374-388.

Ducruet C. (2017) Multilayer dynamics of complex spatial networks: the case of global maritime flows (1977-2008). Journal of Transport Geography, 60: 47-58.

Ducruet C., Lee S.W., Ng A.K.Y. (2010) Centrality and vulnerability in liner shipping networks: revisiting the Northeast Asian port hierarchy. Maritime Policy and Management, 37(1): 1736.

Ducruet C., Notteboom T.E. (2012) The worldwide maritime network of container shipping: Spatial structure and regional dynamics. Global Networks, 12(3): 395-423.

Ducruet C., Notteboom T.E., De Langen P.W. (2009) Revisiting inter-port relationships under the New Economic Geography research framework. In: Notteboom T.E., Ducruet C., De Langen P.W. (Eds.), Ports in Proximity: Competition and Coordination among Adjacent Seaports, Surrey: Ashgate Publishing Limited, pp. 11-27.

Fleming D.K., Hayuth Y. (1994) Spatial characteristics of transportation hubs: centrality and intermediacy. Journal of Transport Geography, 2(1): 3-18.

Fraser D.R., Notteboom T.E., Ducruet C. (2016) Peripherality in the global container shipping network: the case of the Southern African container port system. Geojournal, 81(1): 139-151.

Gerden E. (2015) Black Sea port volumes decline deepens. The Journal of Commerce, December 4, http://www.joc.com/port-news/european-ports/black-sea-port-volumes-stillsuffering-russia-slowdown_20151204.html (Accessed March 2017)

Gouvernal E., Rodrigue J.P., Slack B. (2012) The divergence of regionalization: the challenges of the Mediterranean ports of Europe. Paper presented at the International Association of Maritime Economists (IAME) Conference, Taipei, Taiwan, September 6-8. 
Grushevska K., Notteboom T.E. (2014) An economic and institutional analysis of multi-port gateway regions in the Black Sea basin. Journal of International Logistics and Trade, 12(2): 22-35.

Informal BG annual report (2014) Black Sea container market study.

Lemarchand A., Joly O. (2009) Regional integration and maritime range. In: Notteboom T.E., Ducruet C., De Langen P.W. (Eds.), Ports in Proximity: Competition and Coordination among Adjacent Seaports, Aldershot: Ashgate, pp. 87-99.

Li Z., Xu M., Shi, Y. (2015) Centrality in global shipping network basing on worldwide shipping areas. Geojournal, 80(1): 47-60.

Mareï N., Ducruet C. (2015) The regionalization of maritime networks: Evidence from a comparative analysis of maritime basins. In: Ducruet C. (Ed.), Maritime Networks: Spatial Structures and Time Dynamics, London and New York: Routledge Studies in Transport Analysis, pp. 330-350.

Notteboom T.E. (2004) Container shipping and ports: an overview. Review of Network Economics, 3(2): 86-106.

Notteboom T.E. (2006) Traffic inequality in seaport systems revisited. Journal of Transport Geography, 14(2): 95-108.

Notteboom T.E. (2009) Complementarity and substitutability among adjacent gateway ports. Environment and Planning A, 41(3): 743-762

Notteboom T.E. (2010) Concentration and the formation of multi-port gateway regions in the European container port system: an update. Journal of Transport Geography, 18(4): 567583

Notteboom T.E. (2011) An application of multi-criteria analysis to the location of a container hub port in South Africa. Maritime Policy and Management, 38(1): 51-79.

Notteboom T.E. (2012) Towards a new intermediate hub region in container shipping? Relay and interlining via the Cape route vs. the Suez route. Journal of Transport Geography, 22: 164-178.

Notteboom T.E., de Langen P.W. (2015) Container port competition in Europe. In: Lee C.Y., Meng Q. (Eds.), Handbook of Ocean Container Transport Logistics, Springer International Publishing, pp. 75-95.

Notteboom T.E., Rodrigue J.P. (2005) Port regionalization: towards a new phase in port development. Maritime Policy and Management, 32(3): 297-313 
Rodrigue J.P., Comtois C., Slack B. (2013) The Geography of Transport Systems. London and New York: Routledge.

Rodrigue J.P., Notteboom T.E. (2010) Foreland-based regionalization: Integrating intermediate hubs with port hinterlands. Research in Transportation Economics, 27(1): 19-29.

Thorez P. (1998) La difficile mutation des transports maritimes dans la C.E.I. Bulletin de I'Association des Géographes Français, 75(1): 10-29.

Ugurlu U. (2017) The new Black Sea port. The Medi Telegraph, December 4, http://www.themeditelegraph.com/en/transport/ports/2017/02/04/the-new-black-seaport-reportage-eAzWNhvLQaBJIPHbwiCgrl/index.html

Wang J.J., Ng A.K.Y. (2011) The geographical connectedness of Chinese seaports with foreland markets: A new trend? Tijdschrift voor Economische en Sociale Geografie, 102(2): 188-204. 


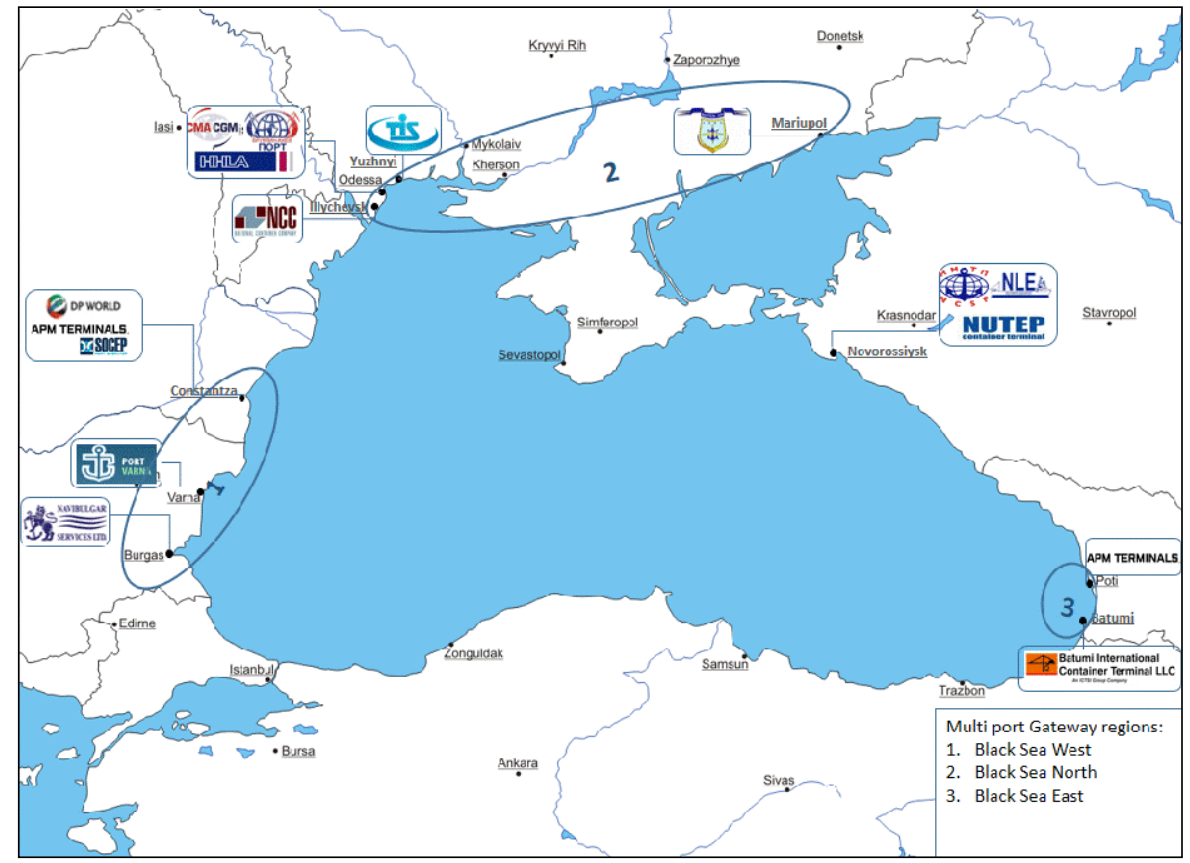

Figure 8.1: Ports of the Black Sea container port system

Source: Grushevska and Notteboom (2014)

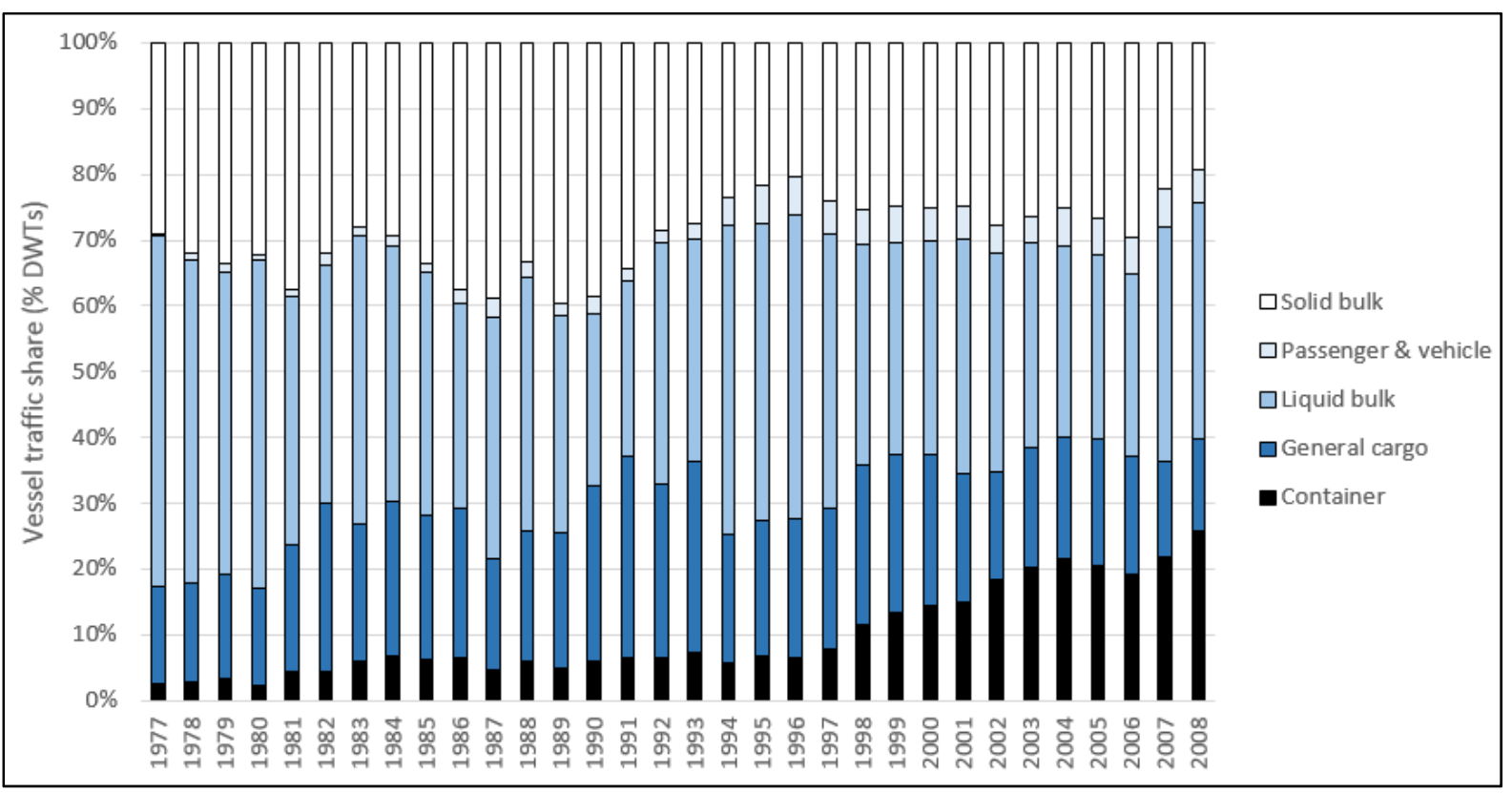

Figure 8.2: Black Sea shipping traffic evolution by main vessel types, 1977-2008 


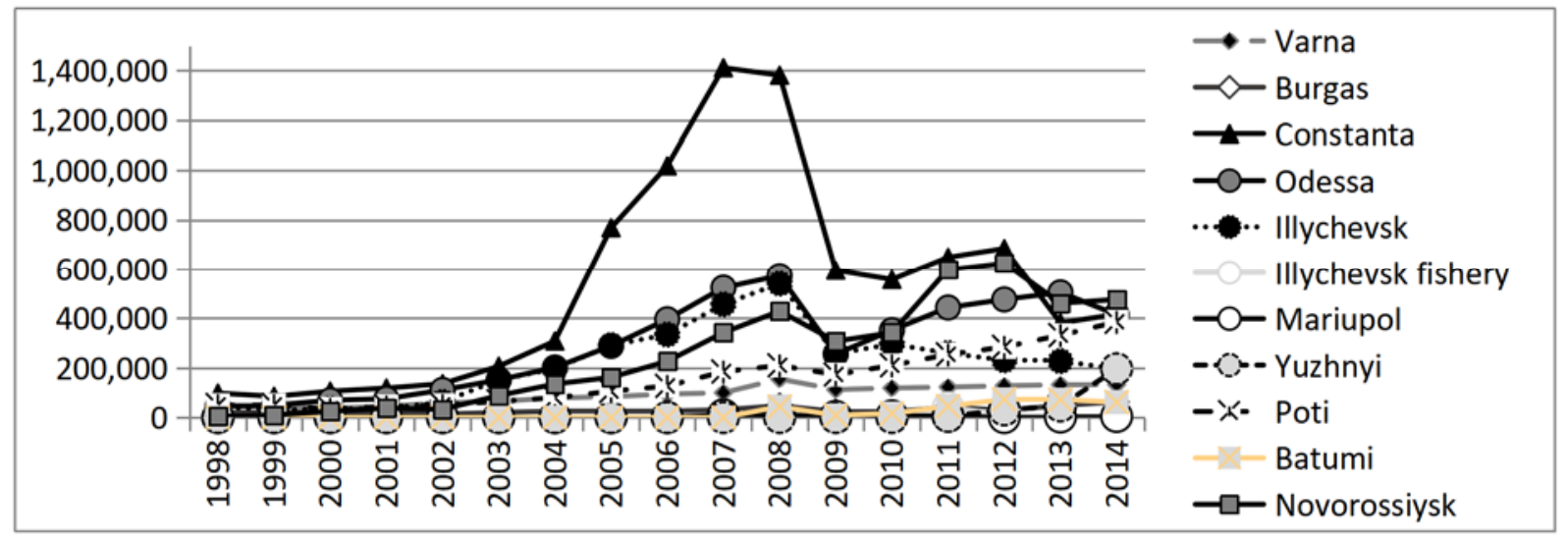

Figure 8.3: Ports of the Black Sea ports container traffic, TEUs

Source: Ports of Ukraine

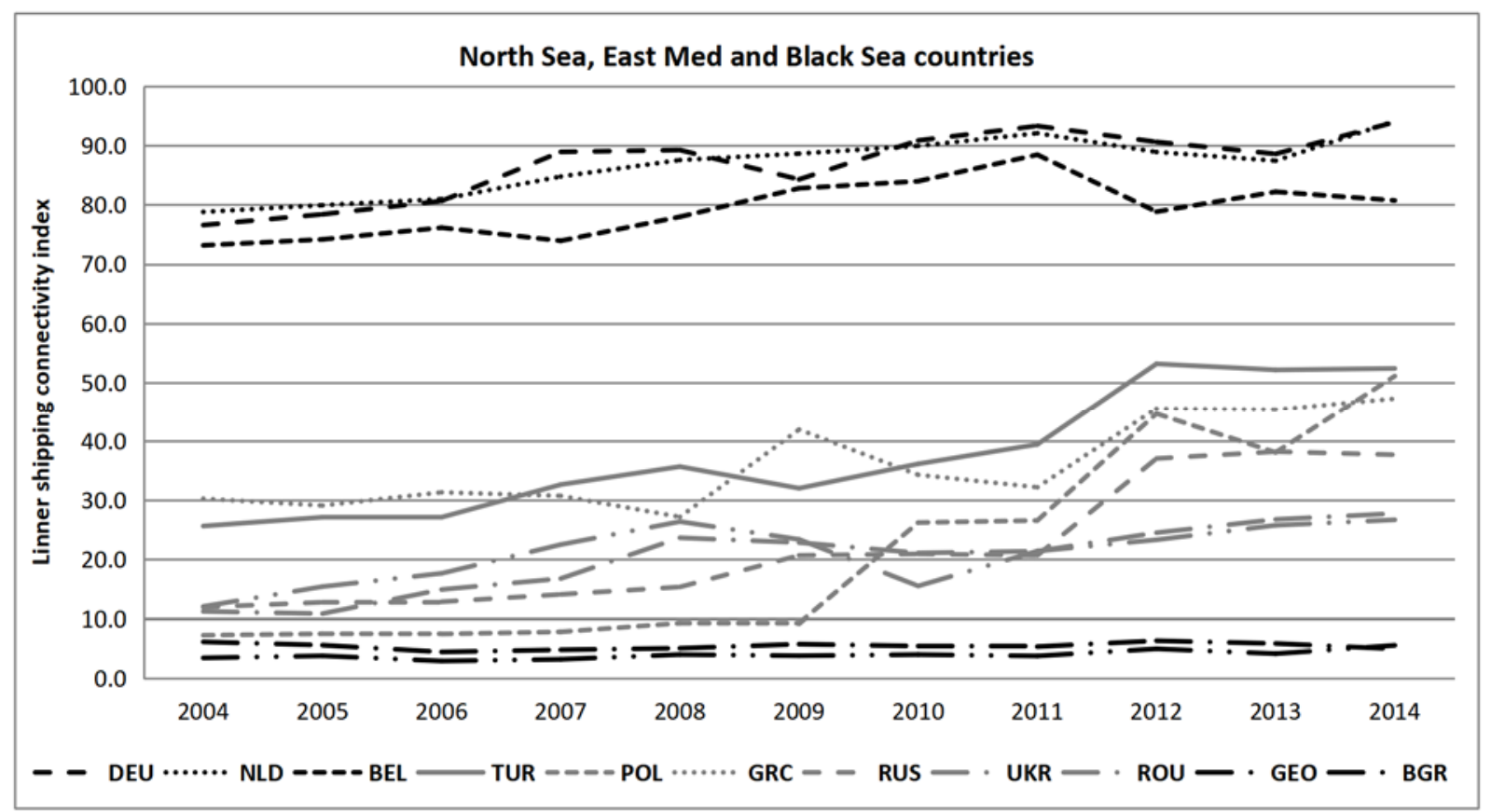

Figure 8.4: Liner Shipping Connectivity Index (North Sea, East Med and Black Sea countries)

Source: UNCTAD 


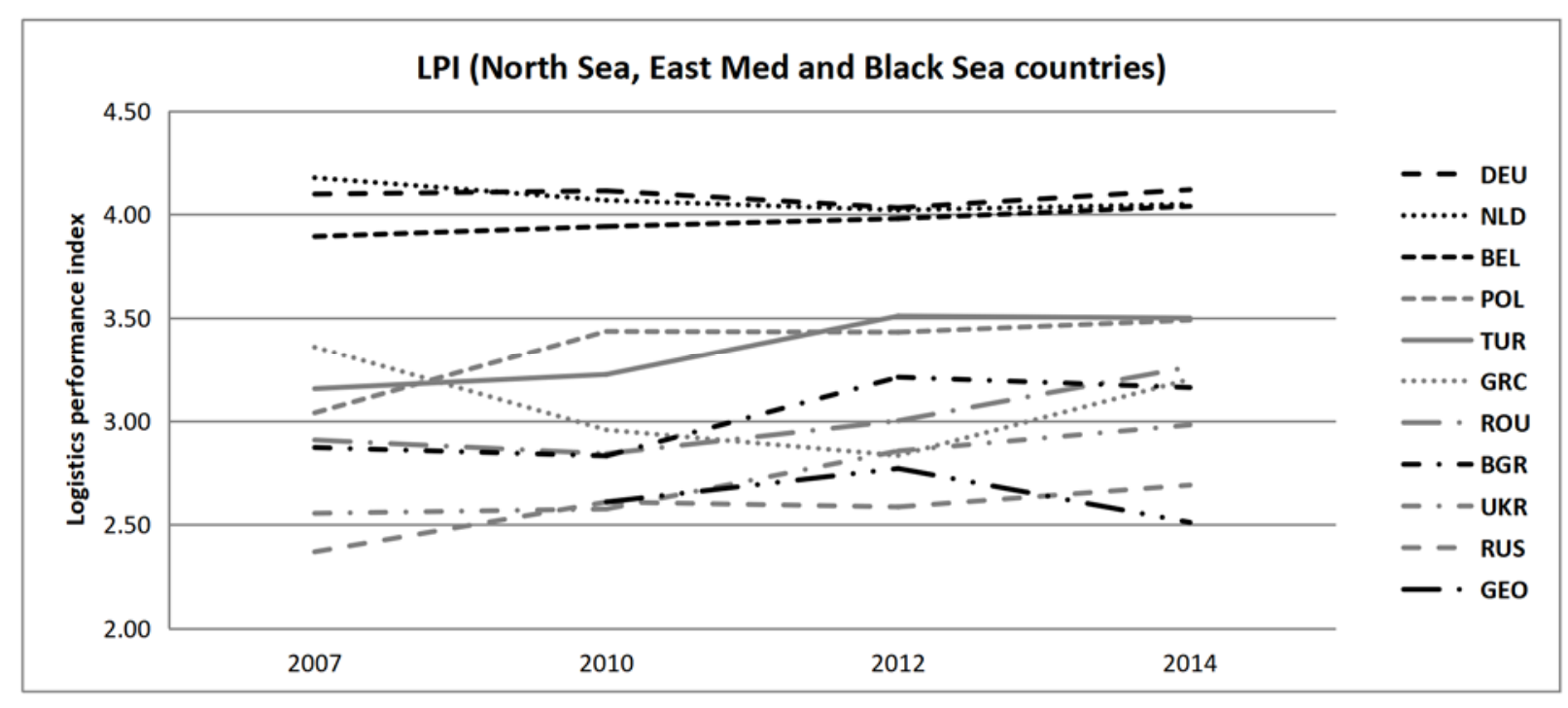

Figure 8.5: LPI (North Sea, East Med and Black Sea)

Source: data.worldbank.org
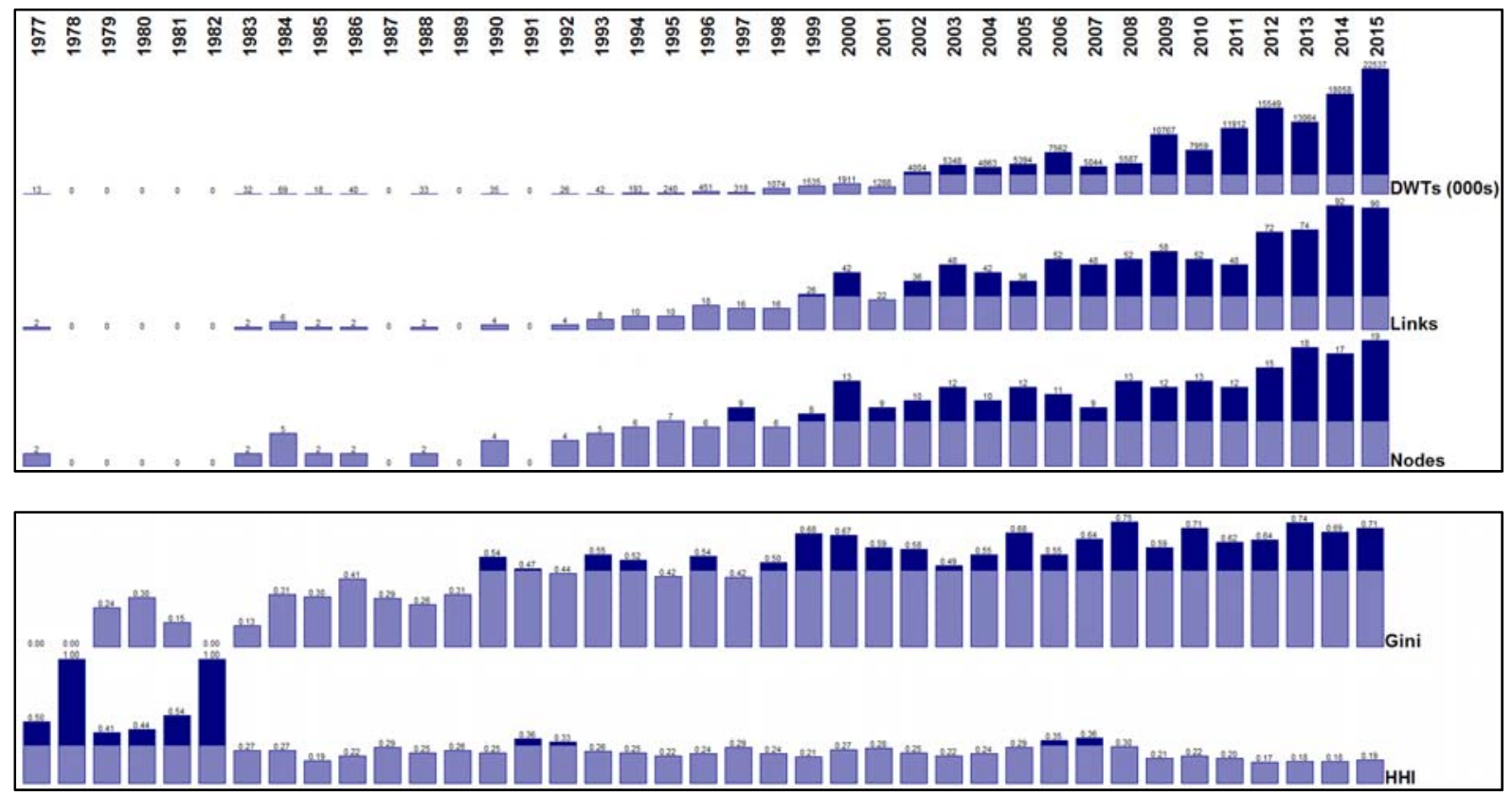

Figure 8.6: Size and traffic evolution of the Black Sea shipping network, 1977-2015

Source: own realization based on $L L I$ data

N.B. values higher than row average are marked in bold 


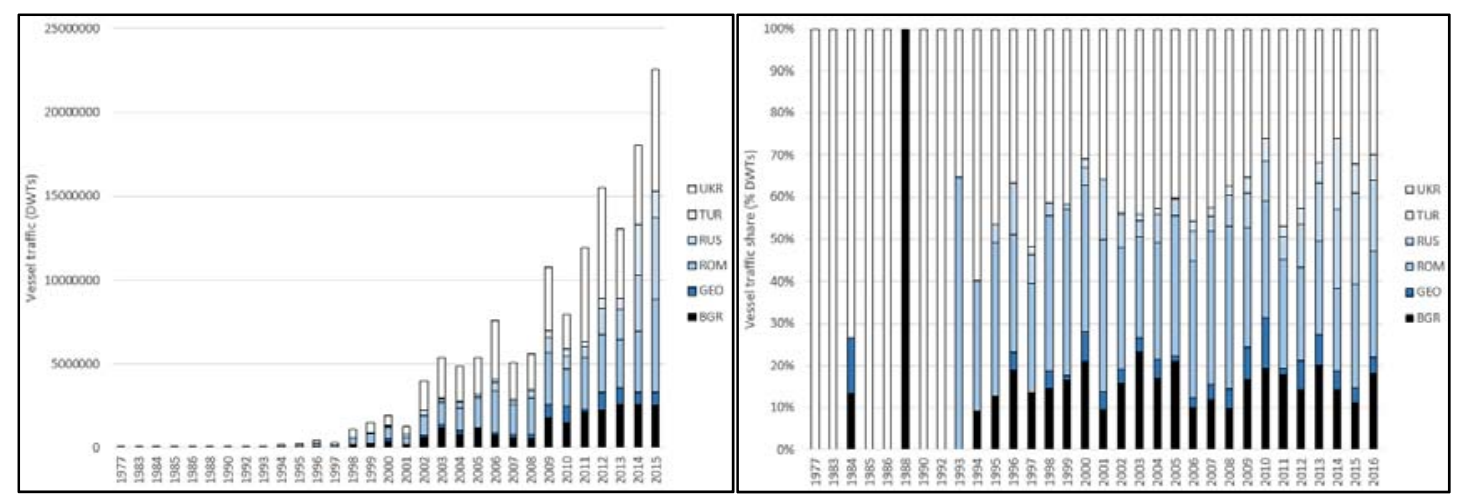

Figure 8.7: Vessel traffic distribution among Black Sea countries, 1977-2015

Source: own realization based on LLI data

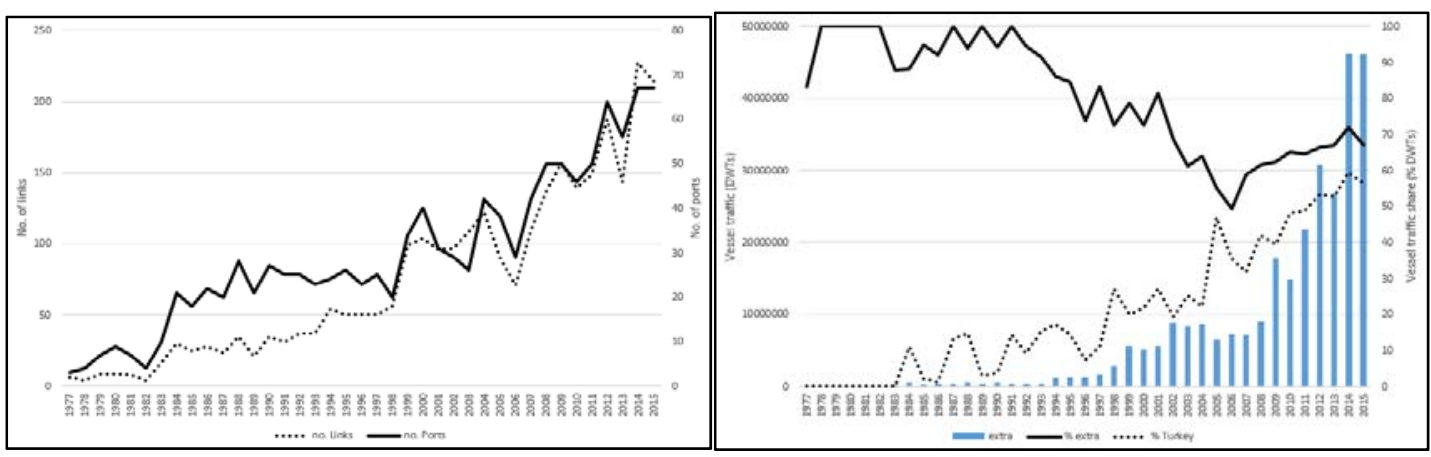

Figure 8.8: External connectivity of Black Sea ports, 1977-2015

Source: own realization based on $L L I$ data

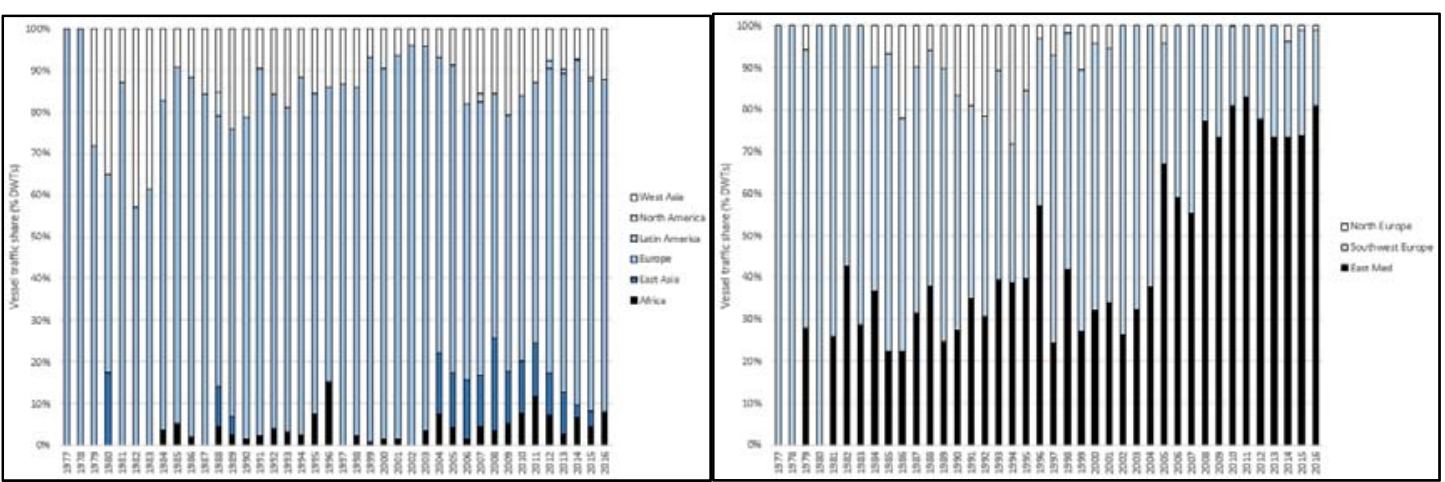

Figure 8.9: Maritime foreland distribution of Black Sea ports, 1977-2016

Source: own realization based on $L L I$ data 

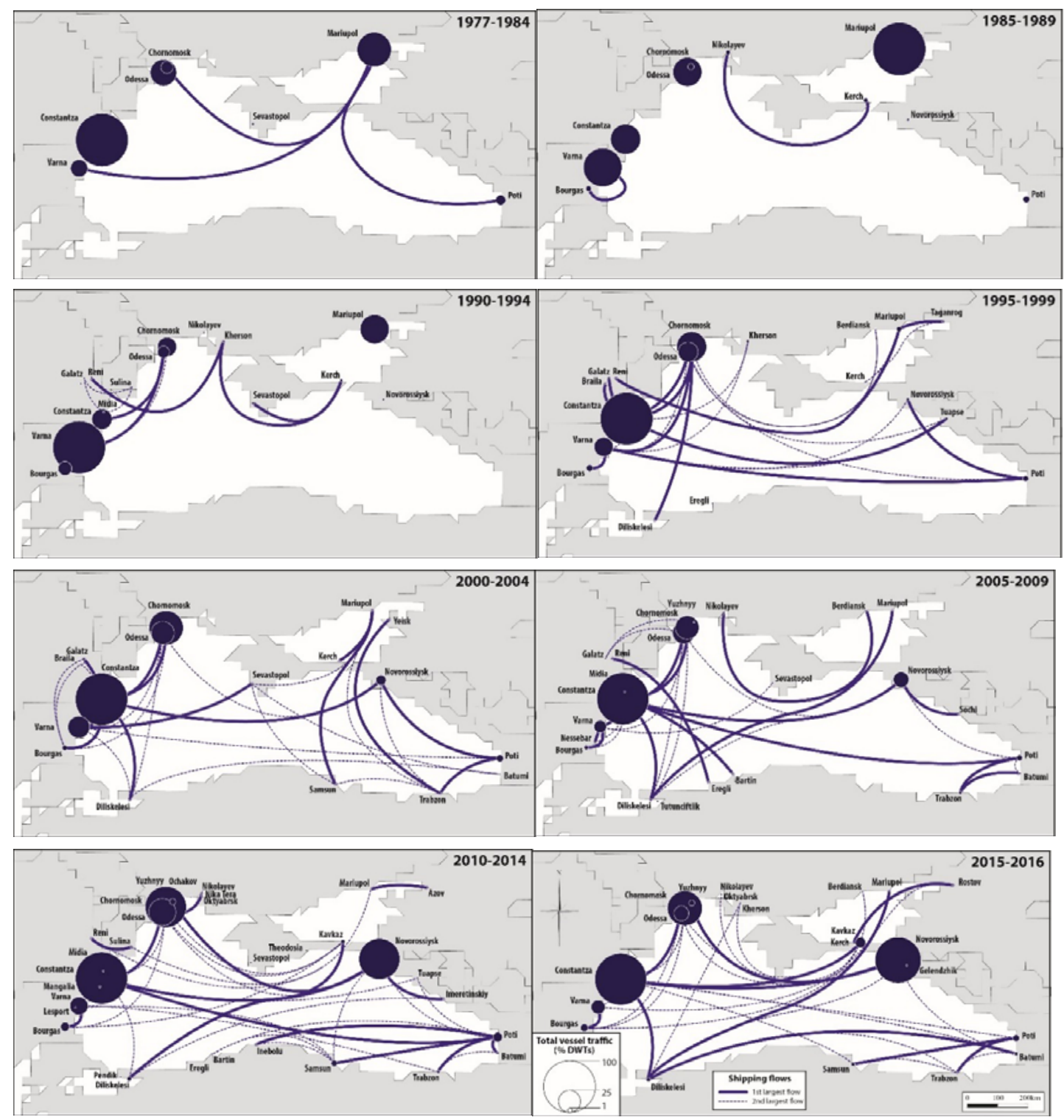

Figure 8.10: Multiple linkage analysis of the Black Sea shipping network, 1977-2016

Source: own realization based on LLI data 


\begin{tabular}{|c|c|c|c|c|}
\hline Shipping line & TEU (2013) & TEU (2014) & share, \% (2013) & share, \% (2014) \\
\hline MSC & 446,620 & 445,133 & $28 \%$ & $28 \%$ \\
\hline MAERSK & 393,080 & 359,568 & $24 \%$ & $23 \%$ \\
\hline CMA CGM & 193,683 & 170,397 & $12 \%$ & $11 \%$ \\
\hline ZIM & 166,172 & 193,159 & $10 \%$ & $12 \%$ \\
\hline ARKAS & 127,969 & 136,889 & $8 \%$ & $9 \%$ \\
\hline$E M C$ & 66,951 & 62,941 & $4 \%$ & $4 \%$ \\
\hline CSAV & 61,250 & 52,929 & $4 \%$ & $3 \%$ \\
\hline$C S C L$ & 58,583 & 59,411 & $4 \%$ & $4 \%$ \\
\hline$H L$ & 50,201 & 71,481 & $3 \%$ & $5 \%$ \\
\hline$Y M L$ & 42,630 & 32,384 & $3 \%$ & $\mathbf{2 \%}$ \\
\hline Total & $\mathbf{1 , 6 0 7 , 1 3 9}$ & $\mathbf{1 , 5 8 4 , 2 9 2}$ & $\mathbf{1 0 0 \%}$ & $\mathbf{1 0 0 \%}$ \\
\hline
\end{tabular}

Table 1. Top 10 container lines calling Black Sea (full containers)

Source: Ports of Ukraine 


\begin{tabular}{|c|c|c|c|}
\hline $\begin{array}{l}\text { Shipping } \\
\text { Company }\end{array}$ & Liner Services & $\begin{array}{l}\text { Vessel size } \\
\text { (TEU) }\end{array}$ & Rotation \\
\hline \multicolumn{4}{|l|}{ Caribbean } \\
\hline Maersk Line & $\begin{array}{l}\text { Med-Caribbean- } \\
\text { Panama service - String } \\
\text { of Ecumed }\end{array}$ & $2800-3200$ & $\begin{array}{l}\text { Algeciras, Marsaxlokk, Izmit Korfezi, Istanbul-Ambarli, Yuzhny, } \\
\text { Novorossisk (NCSP), Istanbul-Ambarli, Istanbul-Evyap, Izmir, } \\
\text { Marsaxlokk, Algeciras, Caucedo, Manzanillo (Pan) ...(WCSA)... } \\
\text { Manzanillo (Pan), Algeciras }\end{array}$ \\
\hline \multicolumn{4}{|l|}{ Middle East-India } \\
\hline Maersk Line & $\begin{array}{l}\text { Black Sea-East Med- } \\
\text { Middle East-India } \\
\text { service (ME-3 / Prime } \\
\text { 3) }\end{array}$ & $\begin{array}{l}4200-5000 \\
8 \times 5500\end{array}$ & $\begin{array}{l}\text { Port Said (SCCT), Mersin, Istanbul-Ambarli, Izmit Korfezi, Novorossisk } \\
\text { (Nutep), Izmit Korfezi, Istanbul-Ambarli, Izmir, Mersin, Jeddah, Jebel } \\
\text { Ali, Pipavav, Hazira, Mumbai-Nhava Sheva, Jebel Ali, Salalah, Port } \\
\text { Said (SCCT) }\end{array}$ \\
\hline \multicolumn{4}{|l|}{ East Asia } \\
\hline $\begin{array}{l}\text { CSCL / K Line / } \\
\text { Yang Ming / PIL / } \\
\text { Wan Hai } \\
\text { Suspended }\end{array}$ & $\begin{array}{l}\text { Asia-Black Sea service } \\
\text { (ABX / CBX / SB 1 / SBS) } \\
\text { (Zim : ABS) }\end{array}$ & 5500 & $\begin{array}{l}\text { Piraeus, Istanbul-Ambarli, Ilichevsk, Constantza, Port Kelang, } \\
\text { Shanghai, Ningbo, Shekou, Singapore, Port Kelang, Piraeus }\end{array}$ \\
\hline $\begin{array}{l}\text { 2M (Maersk / } \\
\text { MSC) } \\
\text { Temporarily } \\
\text { suspended }\end{array}$ & $\begin{array}{l}\text { Asia-Med Loop } 5 \text { (AE-3 } \\
\text { / Black Sea / BEX) }\end{array}$ & 8500 & $\begin{array}{l}\text { Istanbul-Evyap (Izmit), Istanbul-Ambarli, Constantza, Odessa. } \\
\text { Ilichevsk, Istanbul, Piraeus, Port Said (SCCT), Singapore, Xiamen, } \\
\text { Busan, Qingdao, Shanghai, Ningbo, Yantian, Chiwan, Singapore, Port } \\
\text { Kelang, Istanbul-Evyap }\end{array}$ \\
\hline $\begin{array}{l}\text { O3/YM ( CMA } \\
\text { CGM / CSCL / } \\
\text { UASC / Yang } \\
\text { Ming) }\end{array}$ & $\begin{array}{l}\text { Asia-Black Sea service } \\
\text { (AE-3 / BEX) } \\
\text { (Bosphorus Express) }\end{array}$ & $\begin{array}{l}11 \times 8700 / 9 \\
300 \text { teu ( } 2 \\
\text { sailings } \\
\text { skipped) }\end{array}$ & $\begin{array}{l}\text { Port Said, Beirut, Piraeus, Iskenderun, Istanbul-Evyap (Izmit), } \\
\text { Istanbul-Ambarli (Avcilar), Constantza, Odessa, Istanbul-Ambarli } \\
\text { (Avcilar), Piraeus, Port Kelang, Dalian, Xingang, Kwangyang, Busan, } \\
\text { Shanghai, Ningbo, Chiwan, Port Kelang, Port Said }\end{array}$ \\
\hline Zim / OOCL & $\begin{array}{l}\text { Asia-East Med Express } \\
\text { service (EMX) (CSCL : } \\
\text { AMX 2) }\end{array}$ & 4250 & $\begin{array}{l}\text { Ashdod, Haifa, Istanbul-Ambarll, Novorossisk, Odessa, Istanbul- } \\
\text { Ambarli, Haifa, Mumbai-Nhava Sheva, Port Kelang, Dachan Bay, } \\
\text { Busan, Shanghai, Ningbo, Dachan Bay, Ashdod }\end{array}$ \\
\hline
\end{tabular}

Table 2. Direct calls to Black Sea ports (situation for January 2016)

Source: own compilation based on data Alphaliner 